\title{
Elasticity modulus and damping ratio of macaw palm rachillas
}

\author{
Flora Maria de Melo Villar ${ }^{1}$ Francisco de Assis de Carvalho Pinto ${ }^{2}$ Fábio Lúcio Santos ${ }^{3}$ \\ José Antônio Saraiva Grossi ${ }^{2}$ Nara Silveira Velloso ${ }^{4}$
}

\author{
${ }^{1}$ Departamento de Engenharia Agrícola, Universidade Federal de Viçosa (UFV), 36570-900, Viçosa, MG, Brasil. E-mail: flora.villar@ufv.br. \\ Corresponding author. \\ ${ }^{2}$ Universidade Federal de Viçosa (UFV), Viçosa, MG, Brasil. \\ ${ }^{3}$ Universidade Federal de Lavras (UFLA), Lavras, MG, Brasil. \\ ${ }^{4}$ Programa de Pós-graduação em Engenharia Agrícola, Universidade Federal de Lavras (UFLA), MG, Brasil.
}

\begin{abstract}
The macaw palm has been identified as a prime feed stock for biodiesel industries in the near future coming decades. However there are no machines for harvesting and detaching fruits in the biofuel industry; hence, the study of the dynamic behavior of the fruit-rachilla system would aid in the development of such machines. Thus, this study seeks to determine the modulus of elasticity and the damping ratio of four different plant accessions obtained from the Active Germplasm Bank of the Universidade Federal de Viçosa (UFV). Tensile testing was conducted to determine the modulus of elasticity. From the graphical results of tension versus specific strain, it was possible to determine the modulus of elasticity by using the tangent method. To determine the damping ratio, the logarithmic decrement method was performed using vibration testing. Vibration test consisted of a generated impulse of $100 \%$ of the amplitude of acceleration that was used to excite the system. The acquisition of the generated information was performed by a piezoelectric accelerometer. The average modulus of elasticity ranged from 2.22 to $3.17 \mathrm{MPa}$, and the average damping ratios ranged from 0.04 to 0.08 . Thus, the macaw fruit-rachilla was an under-damped system. Key words: Acrocomia aculeata, dynamic behavior, mechanical properties.
\end{abstract}

Módulo de elasticidade e razão de amortecimento das ráquilas da macaúba

RESUMO: A macaúba tem sido apontada como uma das principais matérias-primas para a indústria de biodiesel nas próximas décadas. No entanto, não existem máquinas para colheita ou destacamento dos frutos na usina e o estudo do comportamento dinâmico do sistema fruto-ráquila nortearia o desenvolvimento dessas máquinas. Dessa forma, objetivou-se determinar o módulo de elasticidade e a razão de amortecimento de quatro acessos provindos do Banco Ativo de Germoplasma da UFV. Foi realizado teste de tração para determinar o módulo de elasticidade. A partir dos resultados obtidos na forma gráfica, tensão versus deformação específica, foi determinado o módulo de elasticidade pelo método da tangente. Para determinar a razão de amortecimento, foi empregado o método do decremento logarítmico, realizado por meio de teste de vibração. O teste de vibração constituiu-se de um impulso para excitar o sistema. A aquisição das informações geradas foi realizada por meio de acelerômetro piezelétrico. O módulo de elasticidade médio ficou entre 2,22 e 3,17MPa e as razões de amortecimento médias ficaram entre 0,04 e 0,08. Concluiu-se que o sistema fruto-ráquila da macaúba é subamortecido.

Palavras-chave: Acrocomia aculeata, comportamento dinâmico, propriedades mecânicas.

\section{INTRODUCTION}

Owing to the difficulty of reaching the macaw palm clusters, fruit is harvested by cutting the bunches with a scythe and catching them in a surrounding net as they fall to the ground, or picking up the detached fruit from the ground. To detach the fruit in a factory, or in the field, it may be possible to employ machines that use the principle of mechanical vibration. However, there are no machines available on the market for this purpose; hence, the study of the dynamic behavior of the fruit-rachilla system would aid in the development of such machines.

Among the mechanical properties relevant to the study of the dynamic behavior of the macaw palm fruit-rachilla system, the modulus of elasticity of the rachilla is of utmost importance, as a material, which undergoes elastic deformation when subjected to tension.

Generally, in biological materials the tensile deformation behavior is influenced by time, and we can characterize a material as viscoelastic. In such cases, viscoelastic materials do not present elastic constants; but, rather, deformation is a function of time (LAURENTI, 1997). In practice, there are few elastically isotropic materials; however, many materials are considered isotropic for the purpose of elastic deformation analysis.

In view of the need to develop new technologies for the macaw palm to become 
commercially profitable to agricultural producers, we must invest in the development of harvesting methods and machines for subsequent harvesting and processing of the fruit. In particular, harvesting machines that harvest by creating mechanical vibrations. Two of the necessary parameters for the study of dynamic behavior of an object are the modulus of elasticity and the damping ratio; and the results of this study will aid in the development of harvesters using mechanical vibration. Thus, our objective is to determine the properties in the fruit-rachilla system to aid in the study of its dynamic behavior.

\section{MATERIALS AND METHODS}

The fruit and rachillas used in the experiment were collected from the Active Germplasm Bank of the Universidade Federal de Viçosa (UFV), and its border. Four different palm accessions were used, identified as BD 27 (from the region of Abaeté/ MG), BD 40 (from the region of Pitangui - Martinho Campos/ MG), BGP 29 (from the region of Prudente de Moraes - Matozinhos/ MG), and BGP 35 (from the region of Mirandópolis/ SP). Accessions that had fruit bunches available at the time of the experiment were chosen.

Determination of properties was performed for clusters with green fruit. Two clusters were cut from each palm, and measurements were taken within $24 \mathrm{~h}$ after collection in the agricultural mechanization laboratory of UFV. Physical properties of the rachillas and fruit were determined in order to characterize the systems, using the average of each accession. To accomplish this task, we used 30, 25, 34, and 29 fruits for accessions BD 27, BD 40, BGP 29 , and BGP 35 , respectively, and 10 rachillas from each accession. Three diameters, a, b, and c, were measured for each fruit, corresponding to the largest, intermediate, and smallest dimensions, respectively. The average diameter of the rachillas were obtained from the average of three diameters measured along the rachilla, one in the intermediate portion and the other two at the extremities. Measurements were taken with Mitutoyo digital calipers with a resolution of $0.01 \mathrm{~mm}$.

The average volume of the rachillas were determined by water column displacement using $100 \mathrm{~mL}$ graduated beakers. The volume of the fruit was estimated from characteristic dimensions by means of Equation 1 (MOHSENIN, 1986).

$V=\frac{\pi(a b c)}{6} 10^{-3}$
In which, $\mathrm{V}=$ fruit volume, $\mathrm{cm}^{3}$;

$\mathrm{a}, \mathrm{b}, \mathrm{c}=$ characteristic dimensions, $\mathrm{mm}$.

To determine the average mass of the fruit and rachillas, a digital precision scale with a precision of $0.001 \mathrm{~g}$ was used. The specific mass was obtained from the mass to volume ratio.

Ten rachillas from each accession were used to determine the modulus of elasticity of rachillas. These rachillas were different from those used for the determination of the physical properties. Rachillas were of standard length, having an intermediate portion of $12 \mathrm{~cm}$.

Ten rachillas were used to determine the damping ratio. These rachillas were different from those used to determine the modulus of elasticity, though from the same accessions, and had a standard length of $13 \mathrm{~cm}$ for accessions BD27 and BGP 35, and $11 \mathrm{~cm}$ for accessions BD 40 and BGP 29. Length of rachillas had different standard sizes, owing to the limitation of the actual sizes available in the different accessions.

Rachillas were considered to be elastically isotropic materials for experimental purposes. The rachilla test body was subjected to tensile testing by fixing it between the grips of an INSTRON universal testing machine, model 3365 , with a $5 \mathrm{kN}$ load capacity, with the intermediate $5 \mathrm{~cm}$ of the test body being the portion tested.

The test bodies were subjected to a preload of $2 \mathrm{~N}$ and, the tests began immediately with a speed of $3 \mathrm{mmmin}^{-1}$ until rupture of the body. Test speed was defined after carrying out the pre-tests and is in accordancd with the range of 2.5 to $30 \mathrm{mmmin}^{-1}$ used by ASABE (American Society of Agricultural and Biological Engineers) in compression testing of vegetable material. Average modulus of elasticity for each accession was determined using the tangent method on the stress-strain curve at 0 to $3 \%$.

The logarithmic decrement method was used to determine the damping ratio of the fruitrachilla system in accordance with Equation 2 proposed by RAO (2008).

$\delta=\ln \frac{x_{i}}{x_{i+1}}=\frac{2 \pi \zeta}{\sqrt{1-\zeta^{2}}}$

In which,

$\delta=$ logarithmic decrement; $\zeta=$ damping ratio of the system; $\mathrm{x}_{\mathrm{i}}=$ amplitude of the signal for time $\mathrm{i}, \mathrm{ms}^{-2}$; $\mathrm{x}_{\mathrm{i}+1}=$ amplitude of successive signal at $\mathrm{x}_{\mathrm{i}}, \mathrm{ms}^{-2}$.

Logarithmic decrement method was performed by vibration testing with a generated impulse of $100 \%$ of the amplitude of acceleration, 
the equivalent of five times the acceleration of gravity $\left(\mathrm{g}_{\mathrm{r}}\right)$. To agitate the fruit-rachilla system, Ling Dynamic Systems (LDS) vibration test system instrumentation was used, comprising a DACTRON brand COMET $_{\text {USB }}$ signal generator, a PA 1000L amplifier, and a V-555 model electromagnetic shaker manufactured by LDS. The fruit-rachilla system was secured to a fixed support at the base of the movable shaker. The fruit was attached to the rachilla between the intermediate portion and the end opposite to the support.

For data acquisition, we used anLW174002 uniaxial piezometric accelerometer with sensitivity of $100.7 \mathrm{mV} \mathrm{g}_{\mathrm{r}}^{-1}$ and a National Instruments NI cDAQ9234 data acquisition module. The accelerometer was of low mass, thus not significantly altering the dynamics of the fruit-rachilla system. The accelerometer was fixed vertically to the fruit to measure the system's vertical acceleration. The generated data were processed to produce a graph of the two successive amplitudes of the signal ( $\mathrm{X}_{\mathrm{i}}$ and $\mathrm{X}_{\mathrm{i}+1}$ ) for the calculation of the average damping ratio $(\zeta)$ of each accession (Equation 2). Data were subjected to descriptive statistical analysis with the aid of the $\mathrm{R}$ computer programming language.

\section{RESULTS AND DISCUSSION}

The characteristic dimensions of the fruit show greater variation among different accessions than within the same accession (Table 1). Some
Active Germplasm Bank macaw palms from the states of Minas Gerais and São Paulo were morphologically characterized in a study carried out by PLATA RUEDA (2014). A high degree of divergence was observed among the progenies studied, and those from the State of São Paulo formed a genetically distinct group different than those from Minas Gerais.

The behavior observed in the tensile tests presented a well-defined elastic deformation interval, as expected (Figure 1).

Using these results, it was possible to determine the modulus of elasticity for each accession (Table 2). According to PIMENTEL GOMES (1987), coefficient of variation values up to $10 \%$ are considered low for agricultural products; and values between 10 and $20 \%$ are medium, between 20 and $30 \%$ are high, and above $30 \%$ are very high. Modulus of elasticity presented a CV greater than $10 \%$ for all accessions, reaching $40.33 \%$ in accession BGP 35, which is considered very high both within the same accession and among different accessions. This variation can be attributed to shapes of tested bodies, which were considered cylindrical for the tests, though they were not entirely regular, thus influencing the results.

In general, time influences stress-strain behavior in biological materials, though, the fruitrachilla system was considered elastic and isotropic for elastic deformation analysis since it presented a well-defined elastic portion. The great variation in

Table 1 - Statistical description of the characteristic dimensions of the fruit and rachillas: mass, volume, and specific mass of the rachillas; and mass, volume, and specific mass of the fruit, based on the overall average of all accessions.

\begin{tabular}{|c|c|c|c|c|}
\hline & $\mathrm{a}(\mathrm{mm})$ & $\mathrm{b}(\mathrm{mm})$ & $\mathrm{c}(\mathrm{mm})$ & $\mathrm{d}(\mathrm{mm})$ \\
\hline Average & 43.29 & 42.85 & 41.07 & 3.74 \\
\hline Standard deviation & 3.38 & 3.48 & 3.55 & 0.48 \\
\hline \multirow[t]{2}{*}{ CV $(\%)$} & 7.80 & 8.13 & 8.64 & 12.94 \\
\hline & $\mathrm{m}_{\mathrm{r}}(\mathrm{g})$ & & $\mathrm{V}_{\mathrm{r}}\left(\mathrm{cm}^{3}\right)$ & $\rho_{\mathrm{r}}\left(\mathrm{gcm}^{-3}\right)$ \\
\hline Average & 2.32 & & 3.65 & 0.65 \\
\hline Standard deviation & 0.67 & & 0.82 & 0.20 \\
\hline \multirow[t]{2}{*}{ CV $(\%)$} & 28.92 & & 22.34 & 30.11 \\
\hline & $\mathrm{m}_{\mathrm{f}}(\mathrm{g})$ & & $V_{\mathrm{f}}\left(\mathrm{cm}^{3}\right)$ & $\rho_{\mathrm{f}}\left(\mathrm{gcm}^{-3}\right)$ \\
\hline Average & 44.38 & & 4.06 & 1.10 \\
\hline Standard deviation & 10.63 & & 0.98 & 0.09 \\
\hline CV $(\%)$ & 23.95 & & 24.17 & 8.35 \\
\hline
\end{tabular}

a- largest dimension of the fruit; b-intermediate dimension of the fruit; $c$ - smallest dimension of the fruit; $d$-average dimension of the rachillas; $\mathrm{CV}$-coefficient of variation; $\mathrm{m}_{\mathrm{r}}$ - average mass of rachillas; $\mathrm{V}_{\mathrm{r}}$ - average volume of rachillas; $\rho_{\mathrm{r}}-$ average specific mass of rachillas; $\mathrm{m}_{\mathrm{f}}-$ average mass of fruit; $\mathrm{V}_{\mathrm{f}}$ - average volume of fruit; $\rho_{\mathrm{f}}-$ average specific mass of fruit. 


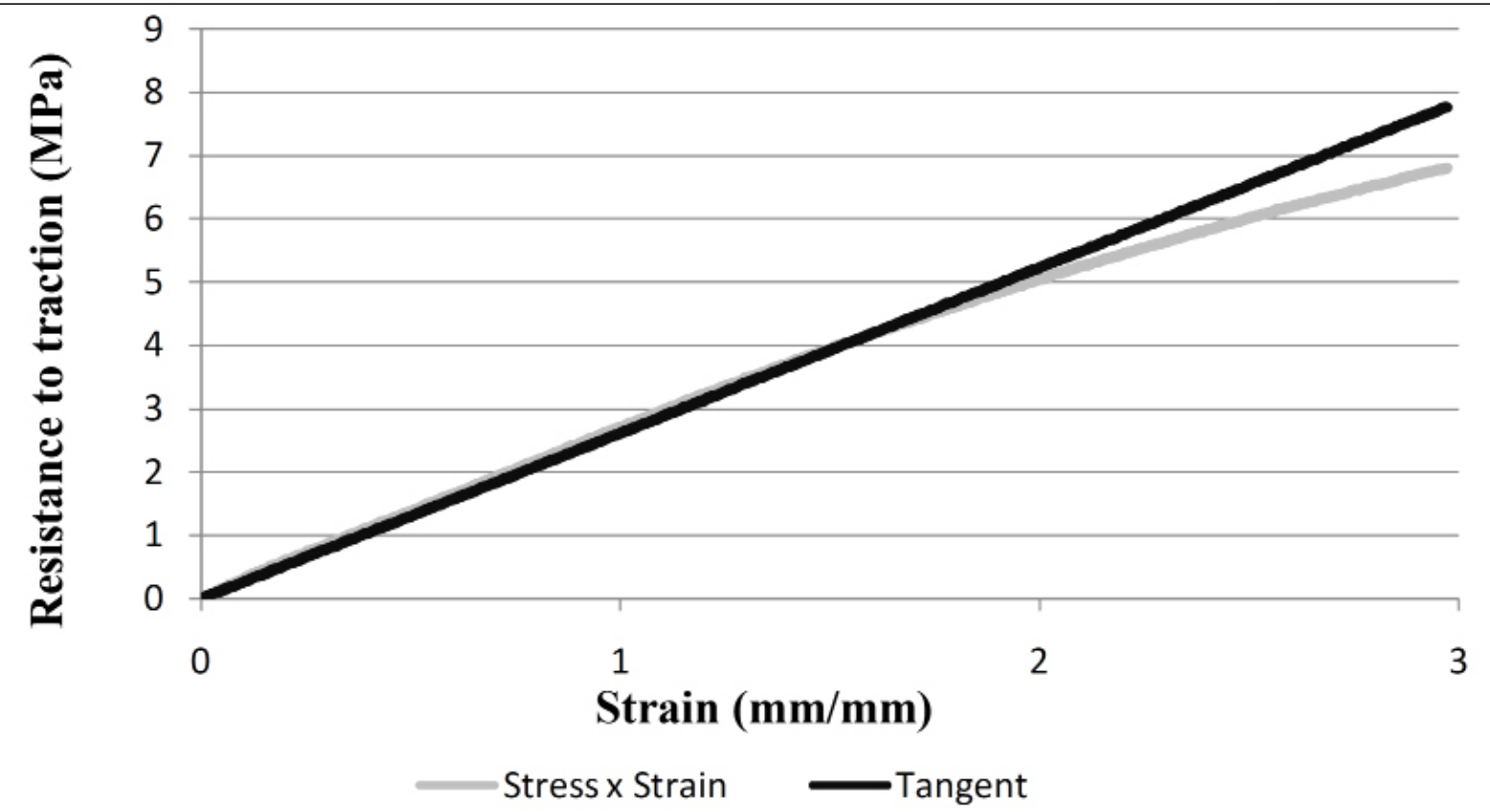

Figure 1 - Stress-strain curve for one of the fruit-rachilla systems and the corresponding tangent curve for determining the modulus of elasticity.

the modulus of elasticity may also be related to this characteristic, given that it is an approximation.

For soya, RIBEIRO et al. (2007) reported values for the modulus of elasticity, analyzing different axes, to be between 10.2 and $23.1 \mathrm{MPa}$ for moist grains. In a study on coffee stalks, using green fruit, COELHO et al. (2015) reported a modulus of elasticity of $3.91 \mathrm{MPa}$.

The decay observed after the impulse corresponds to the behavior of an under-damped body (Figure 2), in which the mass oscillates with amplitudes that diminish exponentially until movement ceases.
Damping ratios obtained confirm that the fruit-rachilla system is under-damped given that the average values were always below one (Table 3 ), as determined by COELHO et al. (2015) for coffee plant branch stems.

When a system undergoes forced vibration, its amplitude tends to increase when near a state of resonance; however, damping tends to diminish the energy transmitted. In mechanical harvesting by mechanical vibration, as in the case of coffee, with the right combination of frequency and amplitude of vibration, it is possible to transfer enough vibrational energy to dislodge the fruit (FERREIRA JÚNIOR et

Table 2 - Statistical description of the modulus of elasticity for accessions BD 27, BD 40, BGP 29 and BGP 35.

\begin{tabular}{|c|c|c|c|c|c|}
\hline & BD 27 & $\mathrm{BD} 40$ & BGP 29 & BGP 35 & All accessions \\
\hline & 2.95 & 3.02 & 3.17 & 2.22 & 2.84 \\
\hline Standard deviation & 0.52 & 0.98 & 0.85 & 0.89 & 0.91 \\
\hline $\mathrm{CV}(\%)$ & 17.73 & 32.42 & 26.88 & 40.33 & 32.00 \\
\hline
\end{tabular}

E - Modulus of elasticity; CV - coefficient of variation; BD 27 - accession from Abaeté/ MG; BD 40 - accession from Pitangui-Martinho Campos/ MG; BGP 29 - accession from de Prudente de Moraes Matozinhos/ MG; BGP 35 - accession from Mirandopólis/ SP. 


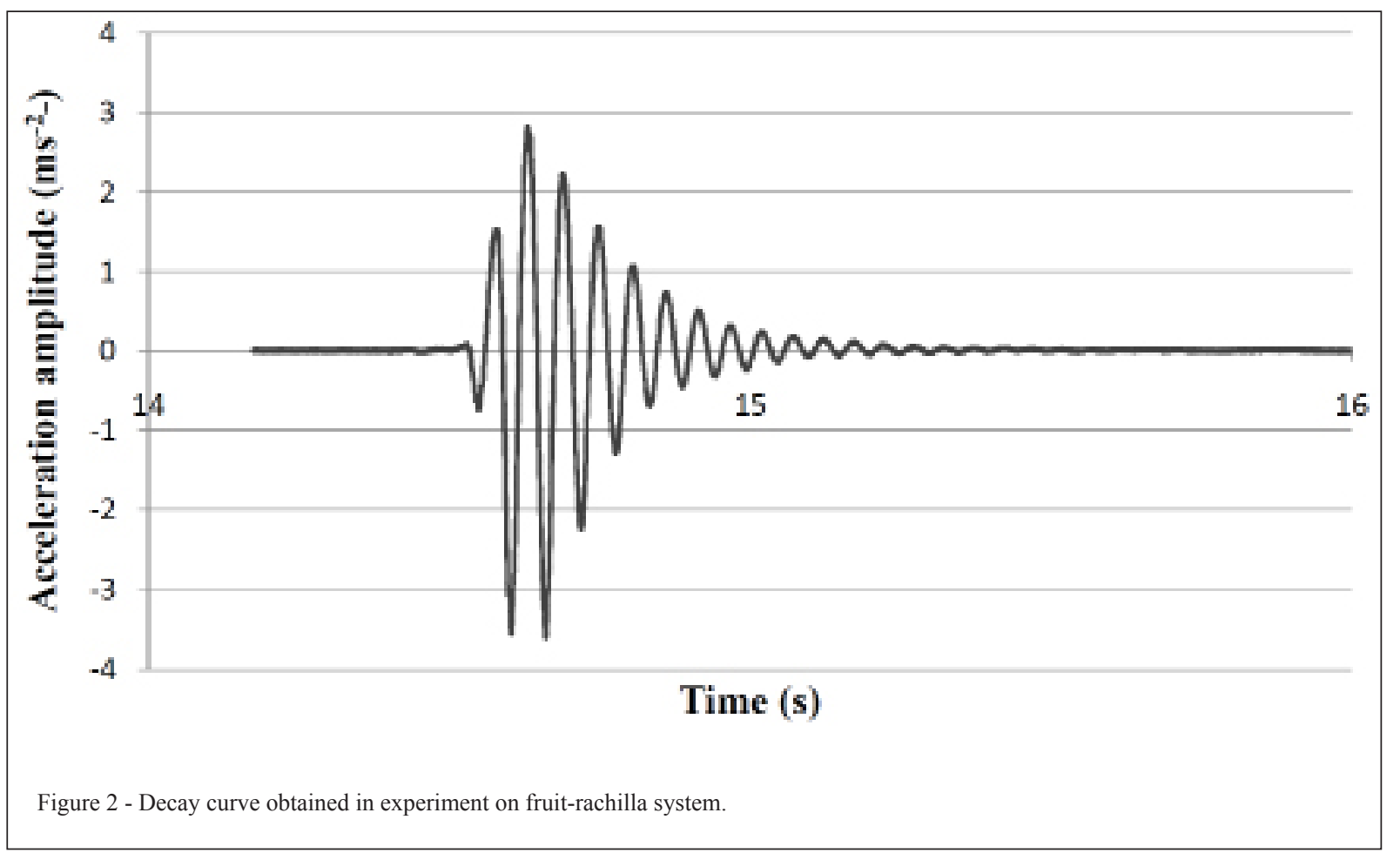

al., 2016). In the case of under-damped systems, the greater the damping ratio, the lower the free vibration amplitude. With a lower damping ratio of the system, there is a tendency for the damped natural frequency to approach the undamped natural frequency, which occurred in the fruit-rachilla systems studied, given that the average damping ratio was less than 0.1 in all accessions (RAO, 2008).
Rachillas are a component of the macaw palm fruit cluster; though under studied, they are of fundamental importance for mechanization projects using the principle of vibration to harvest or detach fruit from the clusters. CIRO (2001) determined the mechanical and geometrical properties of the Columbia variety coffee fruitstalk system in three stages of maturation and

Table 3 - Damping ratio of the fruit-rachilla system (FR) for accessions BD 27, BD 40, BGP 29, and BGP 35, determined experimentally.

\begin{tabular}{|c|c|c|c|c|}
\hline$\zeta$ (adimensional) & BD 27 & $\mathrm{BD} 40$ & BGP 29 & BGP 35 \\
\hline FR 1 & 0.01 & 0.12 & 0.08 & 0.04 \\
\hline FR 2 & - & 0.05 & 0.06 & 0.23 \\
\hline FR 3 & - & 0.08 & 0.08 & - \\
\hline FR 4 & 0.02 & 0.11 & 0.09 & 0.06 \\
\hline FR 5 & 0.06 & - & 0.06 & 0.04 \\
\hline FR 6 & 0.05 & 0.10 & 0.02 & 0.05 \\
\hline FR 7 & 0.03 & 0.07 & 0.07 & 0.03 \\
\hline FR 8 & 0.07 & - & 0.02 & 0.06 \\
\hline FR 9 & 0.10 & - & 0.07 & - \\
\hline FR 10 & 0.01 & 0.05 & 0.05 & 0.08 \\
\hline Average & 0.04 & 0.08 & 0.06 & 0.07 \\
\hline
\end{tabular}

FR - fruit-rachilla system; $\zeta$ - damping ratio; BD 27 - accession from Abaeté/ MG; BD 40 - accession from Pitangui-Martinho Campos/ MG; BGP 29 - accession from Prudente de Moraes Matozinhos/ MG; BGP 35 - accession from Mirandopólis/ SP.

Ciência Rural, v.47, n.2, 2017. 
analyzed the dynamic behavior of the system. The author established that the dynamic behavior is highly dependent on the mechanical and geometric properties. FILGUEIRAS (2001), after determining the mechanical and geometric properties of a coffee plant and analyzing its dynamic behavior, established through sensitivity analysis the significant influence of the diameter of branches and trunks in natural vibration frequencies.

In view of the fact that studies on coffee showed that the mechanical and geometrical properties of the fruit-stalk system influence its dynamic behavior, it was expected that the geometric variation of the fruit and rachillas would also directly influence the dynamic behavior of the macaw palm fruit-rachilla system. This should occur as the natural frequencies vary in accordance with the rigidity of the system, which in turn is determined by its geometry and e distribution of the mass in the system.

\section{CONCLUSION}

The modulus of elasticity obtained is within the expected range for vegetable material with elastic behavior. The fruit-rachilla systems are underdamped for the different accessions as they present an average damping ratio of less than one.

\section{ACKNOWLEDGEMENTS}

The authors thank Fundação de Amparo à Pesquisa do Estado de Minas Gerais (FAPEMIG) and Conselho Nacional de Desenvolvimento Científico e Tecnológico $(\mathrm{CNPq})$ for financial support.

\section{REFERENCES}

CIRO, H.J. Coffee harvesting: determination of the natural frequencies of the fruit stem system in coffee trees.
Applied Engineering in Agriculture, v.17, n.4, p.475479, 2001. Available from: <https://www.researchgate.net/ publication/275515078_Coffee_harvesting_I_Determination of_the_natural_frequencies_of_the_fruit_stem_system_in coffee_trees>. Accessed: Aug. 2015.

COELHO, A.L.F. et al. Determinação das propriedades geométricas, físicas e mecânicas do sistema fruto-pedúnculoramo do cafeeiro. Revista Brasileira de Engenharia Agrícola e Ambiental. v.19, n.3, p.286-292, 2015.Available from: <http:// www.scielo.br/pdf/rbeaa/v19n3/1415-4366-rbeaa-19-03-0286. pdf>. Accessed: July 2015.

FERREIRA JÚNIOR, L.G. et al. Recomendação para colheita mecânica do café baseado no comportamento de vibração das hastes derriçadoras. Ciência Rural, Santa Maria, versão online ISSN 0103-8478, v.46, n.32, p.273-278, 2016.

FILGUEIRAS, W.H. Modelagem da planta de café por elementos finitos para estudos de colheita por vibração. 2001. 81f. Dissertação (Mestrado em Engenharia Agrícola) Universidade Federal de Viçosa, Viçosa, MG.

LAURENTI, R. Estudo metodológico das geometrias de corpos vegetais para ensaios mecânicos. 1997. 245f. Dissertação (Mestrado em Engenharia Agrícola, área de concentração: máquinas agrícolas) - Universidade Estadual de Campinas, Campinas, SP

MOHSENIN, N.N. Physical properties of plant and animal materials. New York: Gordon and Breach Publishers, 1986. 841p.

PIMENTEL GOMES, F. A estatística moderna na pesquisa agropecuária. 3. ed. Piracicaba: Potafos,1987. 162p.

PLATA RUEDA, R.A. Avaliação de germoplasma para melhoramento e a conservação da macaúba. 2014. 44f. (Doutorado em Fitotecnia) - Departamento de Fitotecnia, Universidade Federal de Viçosa, Viçosa, MG.

RAO, S. Vibrações mecânicas. 4.ed. São Paulo: Pearson Prentice Hall, 2008. 424p.

RIBEIRO, D.M. et al. Propriedades mecânicas dos grãos de soja em função do teor de água. Engenharia Agrícolal, v.27, n.2, p.493-500, 2007. 


\section{Erratum}

In the "Elasticity modulus and damping ratio of macaw palm rachillas" published in Ciência Rural, volume 47, number 2, DOI http://dx.doi.org/10.1590/0103-8478cr20160289.

\section{In the Abstract, where it reads:}

The average modulus of elasticity ranged from 2.22 to $3.17 \mathrm{MPa}$

\section{Read it:}

The average modulus of elasticity ranged from 194 to $293.3 \mathrm{MPa}$

\section{In the Resumo, where it reads:}

O módulo de elasticidade médio ficou entre 2,22 e 3,17MPa

\section{Read it:}

O módulo de elasticidade médio ficou entre 194 e 293,3MPa

In the Results and Discussion, where it reads:

Modulus of elasticity presented a CV greater than $10 \%$ for all accessions, reaching $40.33 \%$

\section{Read it:}

Modulus of elasticity presented a CV greater than $10 \%$ for all accessions, reaching $31.4 \%$

\section{Where it reads:}

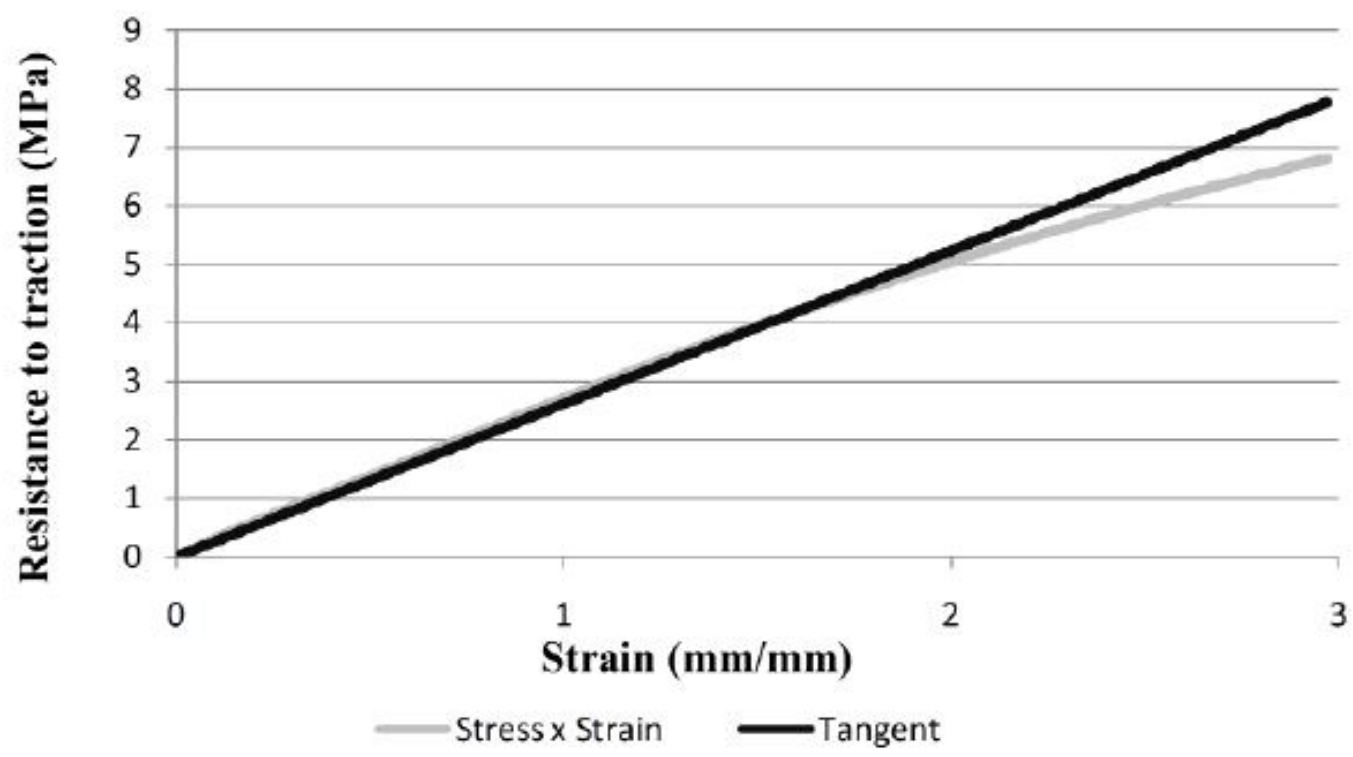




\section{Read it:}

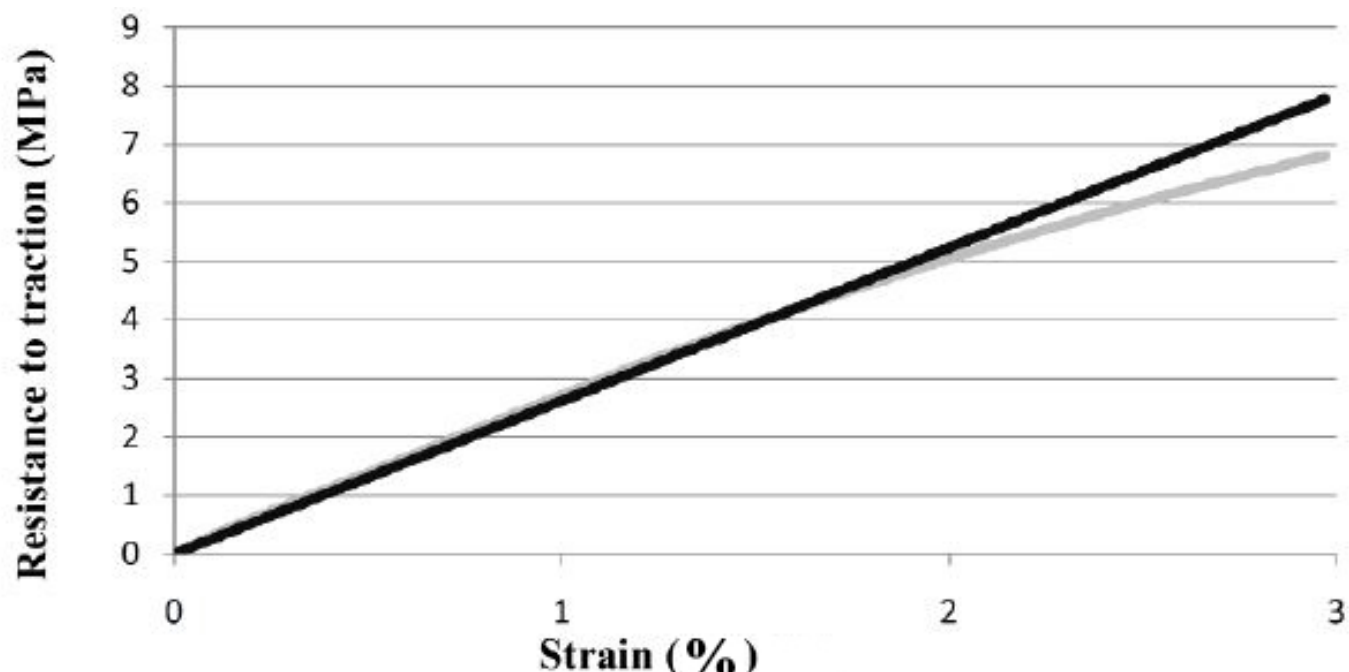

- Stress $\times$ Strain $\quad$ Tangent

\section{Where it reads:}

Table 2 - Statistical description of the modulus of elasticity for accessions BD 27, BD 40, BGP 29 and BGP 35.

\begin{tabular}{|c|c|c|c|c|c|}
\hline & BD 27 & BD 40 & BGP 29 & BGP 35 & All accessions \\
\hline & 2.95 & 3.02 & 3.17 & 2.22 & 2.84 \\
\hline Standard deviation & 0.52 & 0.98 & 0.85 & 0.89 & 0.91 \\
\hline $\mathrm{CV}(\%)$ & 17.73 & 32.42 & 26.88 & 40.33 & 32.00 \\
\hline
\end{tabular}

E - Modulus of elasticity; CV - coefficient of variation; BD 27 - accession from Abaeté/ MG; BD 40 - accession from PitanguiMartinho Campos/ MG; BGP 29 - accession from de Prudente de Moraes Matozinhos/ MG; BGP 35 - accession from Mirandopólis/ SP.

\section{Read it:}

Table 2 - Statistical description of the modulus of elasticity for accessions BD 27, BD 40, BGP 29 and BGP 35.

\begin{tabular}{lccccc}
\hline & & & & & \\
& & & & & \\
& BD 27 & BD 40 & BGP 29 & BGP 35 & All accessions \\
Standard deviation & 238.9 & 260.7 & 293.3 & 194 & 246.9 \\
CV (\%) & 38.4 & 62.7 & 81.4 & 60.9 & 72.4 \\
\hline
\end{tabular}

E - Modulus of elasticity; CV - coefficient of variation; BD 27 - accession from Abaeté/ MG; BD 40 - accession from PitanguiMartinho Campos/MG; BGP 29 - accession from de Prudente de Moraes Matozinhos/ MG; BGP 35 - accession from Mirandopólis/ SP. 